\title{
THE EFFECT OF E-MARKETING WITH AISAS MODEL (Attention, Interest, Search, Action, Share) ON INVESTMENT DECISIONS IN FINTECH SYARIAH
}

\section{Adinda Dian Ramadhani', Abdi Triyanto², Iqbal Fadli Muhammad ${ }^{3}$}

\author{
${ }^{1}$ SEBI: Email: adindadianr@gmail.com \\ ${ }^{2}$ SEBI Lecturer Email : abdi.triyanto@gmail.com \\ ${ }^{3}$ SEBI Lecturer Email : qbalfm37@gmail.com
}

\begin{abstract}
This study aims to examine the effect of E-marketing with the AISAS model on investment decisions. This research using quantitative research. Data was obtained by distributing online questionnaires to 30 respondents, who had or were investing in registered Islamic Fintechs in the Financial Services Authority (OJK). The sampling technique in this study is purposive sampling, while the Structural Equation Modeling (SEM) with the Partial Least Square (PLS) approach is using a data analysis technique. Data is processed using PLS 3.2.8. Based on the results of data analysis, the Attention variable has a significant effect on the Interest variable. Also, the Interest variable has a significant effect on the Search variable. Then, the Search variable has a significant effect on the Action variable, while the Action variable has not a significant effect on the Share variable. The Share variable has not a significant effect on investment decisions.
\end{abstract}

Keywords: E-Marketing, Investment Decisions, AISAS Mode

\section{INTRODUCTION}

According to (Ngafifi, 2014), technological progress is something that cannot be avoided in this life because technological progress will go according to scientific progress. The development of this technology brings considerable influence in various fields. Such as lifestyle, culture, social, education, economy, and others. Likewise, in financial institutions. Advances in technology make significant contributions, especially in terms of ease of transaction. Over time, many innovations produce new technology. By utilizing technological advances, humans can make financial transactions online and not have to meet face to face.

In connection with the use of information technology and innovation in the financial services sector in Indonesia, it is now possible to see significant developments. Various financial services that utilize information technology or often referred to as Financial Technology (Fintech), have become common in the community. Both offered by financial institutions overseen by the FSA (such as services at banks, insurance, insurance, or other registered financial institutions) as well as those offered by startup companies (companies that have not been registered and supervised by OJK). The public has increasingly accepted Fintech because it can provide a variety of services that are relatively attractive, easy to use, and convenient for consumers to use (OJK, 2017). 

Decisions in Fintech Syariah

As technology develops, fintech types are increasingly diverse, including financial technology innovations related to payments and transfers, financial service institutions, and fintech startup companies that use new technology to provide services that are faster, cheaper, and more convenient. Companies in the financing and investment sectors also compete by using technological innovations in selling financial products and services. The types of fintech in this sector include Peer-to-Peer (P2P) Lending, Crowdfunding, Supply Chain Finance, and others (OJK, 2017). However, this research will only discuss fintech related to the type of Peer-to-Peer Lending.

Fintech Peer-to-Peer Lending companies began to be registered with the Financial Services Authority (OJK) and obtained a business license in 2017; there were 19 fintech companies registered with OJK in 2017. Until now, data from (OJK, 2019) as of June 30, there are 113 companies registered or licensed; in other words, companies engaged in fintech continue to grow every year. However, out of 113 registered fintech, only six companies fintech sharia, the remaining 97 companies are well-known fintech companies.

The difficulty of finding a minimum capital of $\mathrm{Rp} 2.5$ billion makes startup financial technology (fintech) sharia schemes challenging to grow. As stated by Murniati Mukhlisin to Republika, "There have been several (sharia fintech) submitted to the OJK. However, there are still very few because they have to have capital of Rp 2.5 billion if they want to be registered. So it is difficult for young people founding fintech Islamic startups to get OJK approval (Republika, 2018).

To find investors in Islamic fintech so that they can increase capital to be registered with the OJK, Islamic fintech can utilize the currently developing technology to promote or introduce fintech products and services using the internet commonly known as e-marketing concepts. According to (Priansa, 2017) electronic marketing is a strategy, system, and marketing process by utilizing internet-based information and communication technology.

According to (Rofiq, Arifin, \& Wilopo, 2012), each company or a marketer has its concepts in marketing a product. In the science of marketing communication, the concept of AIDA is known as a reference in creating a communication campaign program, and often this AIDA concept is the initial foundation in making marketing programs. This model eventually develops until other forms emerge, including AIDMA (Attention, Interest, Desire, Memory, Action), which are more concentrated on the consumption behavior model in the broadcasting world. In the end, now appears AISAS (Attention, Interest, Search, Action, Share), which is a consumption behavior model that was initiated by Dentsu in 2004. This model emerged after the rapid development of the internet in the global world. AISAS is more concentrated on how the consumption of goods and services is carried out, one of which is the significant role of the internet (Wirawan \& Hapsari, 2016).

By using the AISAS Model (Attention, Interest, Search, Action, Share), it is hoped that we can find out what marketing methods are suitable for applying to Islamic fintech? Furthermore, does the AISAS Model influence the public to invest in Islamic fintech? 
Jurnal Ekonomi dan Perbankan Syariah

Vol. 7. No.2, 0ktober 2019: 47-57, ISSN (cet): 2355-1755 | ISSN (online): 2579-6437

\title{
LITERATURE REVIEW
}

\begin{abstract}
AISAS Model
AISAS (Attention, Interest, Search, Action, Share), which is a consumption behavior model initiated by Dentsu in 2004. This model emerged after the rapid development of the internet in the global world. AISAS is more concentrated on how the consumption of goods and services is carried out, one of which is the prominent role of the internet (Wirawan \& Hapsari, 2016).

AISAS is intended as a reflection of the significant role of the internet in human life in the current era. Search and Share positions become essential activities on the internet in finding information in the form of user experience, service levels, and satisfaction. Following is an explanation of each step of the
\end{abstract} AISAS model (Sugiyama \& Andree, 2011) :

1. Attention

The purpose of this phase is to increase consumer attention for a product. A product must be introduced to its target market. With the presence of this internet era, the choice of introducing products can be made through various methods that are relatively inexpensive, such as via e-mail, mailing list, and online media.

2. Interest

Interest is a process when potential customers begin to be interested in our products. This interest can occur because of the right communication for consumers. In the internet age, this interest can also occur if consumers feel attracted to the information displayed on the online media used.

3. Search

Search is a process where consumers will try to find as much information as possible through a search engine before making a decision. Reviews of products can be clearly found on the internet through various forms, for example, through the media of Twitter, Facebook, Instagram, YouTube, and blogs.

4. Action

Action is an action where consumers make a purchase, and where real experience is created, where consumers already feel the product or service. In this section also, the process of direct interaction occurs between consumers and sellers. The purpose of this phase is to provide an opportunity for consumers to make purchases of the product.

5. Share

Share is the result that will be obtained after consumers feel all the experience of their interactions with the product or brand; they will share their experiences with others through online media. The purpose of this phase is to encourage consumers to send quality information about the products they consume. 
50 | Adinda Dian Ramadhani, Abdi Triyanto, Iqbal Fadli Muhammad : The Effect of EMarketing With AISAS Model (Attention, Interest, Search, Action, Share) on Investment Decisions in Fintech Syariah

\section{Investment Decision}

According to (Tandelilin, 2010) the basis of investment decisions consists of the level of expected returns, the level of risk, and the relationship between return and risk.

\section{a. Return}

The main reason people invest is to make a profit. In the context of investment management, the level of return on investment is called return, which is very reasonable if investors demand a specific rate of return on the funds that have been invested. The investor's expected return from his investment is compensation for opportunity costs and the risk of decreasing purchasing power due to the influence of inflation.

b. Risk

Naturally, investors expect the highest return from their investments. However, there are essential things that must always be considered, namely how much risk must be borne from the investment. Generally, the higher the risk, the greater the expected rate of return.

c. Hubungan Tingkat Risiko dan Return Harapan

According to (Tandelilin, 2010) the relationship between risk and return expectation is a direct and linear relationship that means that the higher the risk of an asset, the greater the expected return on the asset, and vice versa.

\section{Kerangka Pemikiran dan Hipotesis}

In finding out the relationship between the role of e-marketing to investment decisions, using the AISAS model on Islamic fintech, a framework is made as shown in the following figure;

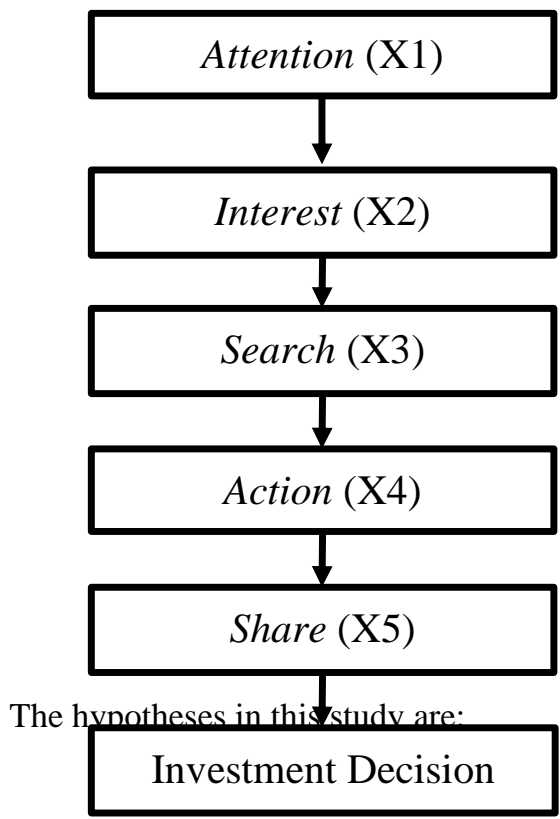


Jurnal Ekonomi dan Perbankan Syariah

Vol. 7. No.2, 0ktober 2019: 47-57, ISSN (cet): 2355-1755 | ISSN (online): 2579-6437

\section{1}

Hypothesis 1: Attention (X1) influences Interest (X2)

Hypothesis 2: Interest (X2) influences Search (X3)

Hypothesis 3: Search (X3) influences Action (X4)

Hypothesis 4: Action (X4) influences Share (X5)

Hypothesis 5: Share (X5) influences the Investment Decision (Y)

\section{RESEARCH METHODOLOGY}

\section{The Scope of Research}

This research is a type of quantitative research. According to (Sugiyono, 2017), this method is called a quantitative method because the research data are in the form of numbers and analysis using statistics. This quantitative research uses a survey method. The survey method is used to describe the relationship between the causal variables studied. This research method aims to find out and analyze how the relationship of the influence of e-marketing using the AISAS model to investment decisions on Islamic fintech.

This survey was conducted to people who have already invested in Islamic fintech by distributing questionnaires to a sample of respondents to get relevant facts about the causal relationship and hypothesis.

The variables in this study use five independent variables: Attention, Interest, Search, Action, Share, and one dependent variable: investment decisions on Islamic fintech. This research was conducted to determine the effect of the independent variables on the dependent variable.

\section{Data Source}

Data sources used in this study are primary and secondary data. According to (Sugiyono, 2017), primary data sources are data obtained from the field directly from the source, while secondary data sources are data not obtained from the field but from libraries or other places that hold references, documents containing proven data its validity.

Primary data in this study were obtained from distributing questionnaires to respondents, while secondary data in this study were obtained from various agencies such as OJK and APJII, literature studies, journals, books, articles of previous research results, and internet searches.

\section{Population and Sample}

The population in this study is infinite; that is, everyone who has invested in Islamic fintech. This study limits the population to people who have invested in sharia fintech registered in the Financial Service Authority (OJK). They are PT Ammana Fintek Syariah, PT Dana Syariah Indonesia, PT Danakoo Mitra Artha, PT Alami Fintek Syariah, PT Syarfi Teknologi Financial, and PT Duha Madani Syariah. To make it easier for researchers to obtain data, then enter a sample that is included in the members of the population. 

Decisions in Fintech Syariah

In line with this, the sampling in this study follows the determination of sample size according to the provisions of Gay and Diehl (1996) in (Sanusi, 2011) that research that examines the relationship between one variable or more is taken at least 30 samples. So in this study, researchers set a sample of 30 respondents.

\section{Method of collecting data}

The purpose of collecting data in scientific research is to obtain data that is relevant, accurate and reliable. The data collection method used in this study is by distributing online questionnaires to people who have invested in Islamic fintechs that have been registered with OJK.

\section{Measuring Scale}

In this study using a Likert scale. According to (Sugiyono, 2017) the Likert scale is used to measure the attitudes, opinions, and perceptions of a person or group of people about social phenomena. In research, the social phenomenon has been specifically determined by the researcher referred to as the research variable.

With a Likert scale, the variables to be measured will be translated into indicator variables. Then the indicator is used as a starting point for arranging instrument items, which can be statements or questions. The answers to each item of instruments that use the Likert scale have gradations from very positive to very negative. In this case, respondents were asked to state the answers strongly agree/agree/ doubt / disagree / strongly disagree with each statement (Sugiyono, 2017). For quantitative research, the answer can be given a score;

a. Very agree / always / very positive are rated score 5

b. Agree / often / positively are given score 4

c. Hesitation / sometimes / neutral are given a score of 3

d. Disagree /rarely/ negative are given score 2

e. Strongly disagree / never / are given a score of 1

\section{Data analysis technique}

Data analysis techniques in this study were carried out with the SEM (Structural Equation Modeling) model with the PLS (Partial Least Square) approach, where this model is a collection of statistical techniques that allow testing of a series of relatively complex and simultaneous relationships. This study uses the SEM model because this study aims to look at the relationship between variables where the variables in the study cannot be measured directly, but require indicators as a measurement tool.

\section{Model Evaluation in PLS}

The evaluation of the PLS model is done by evaluating the outer model and the inner model. The outer model is a measurement model to assess the validity and reliability of the model. Through the algorithm literacy process, 
Jurnal Ekonomi dan Perbankan Syariah

Vol. 7. No.2, 0ktober 2019: 47-57, ISSN (cet): 2355-1755 | ISSN (online): 2579-6437

\section{3}

measurement model parameters (convergent validity, discriminant validity, composite reliability, and Cronbach alpha) are obtained, especially the value of $\mathrm{R}$-square as a parameter of the accuracy of the prediction model. The inner model is a structural model for predicting causality between latent variables. Through the bootstrapping process, T-Statistic test parameters are obtained to predict causality (Abdillah \& Jogiyanto, 2015).

\section{Evaluation of Measurement Model (Outer Model)}

The measurement model is used for testing construct validity and instrument reliability (Abdillah \& Jogiyanto, 2015). This measurement model includes convergent validity and discriminant validity through cross-loading and the average root variance extracted, as well as composite reliability. Evaluations of measurement models are grouped into evaluations of reflective models or formative models (Yamin \& Kurniawan, 2011) :

\section{Convergent Validity}

Convergent validity measures the magnitude of the correlation between constructs and latent variables. In convergent validity evaluation from checking item reliability, it can be seen from the value of the standardized loading factor. The standardized loading factor illustrates the magnitude of the correlation between each measurement item (indicator) and its construct. The loading factor value above 0.7 can be said to be ideal, meaning that the indicator is said to be valid as an indicator that measures constructs. Nevertheless, the standardized loading factor value above 0.5 can be accepted, while the standardized loading factor value below 0.5 can be issued (Yamin \& Kurniawan, 2011).

After we evaluate individual item reliability (through the standardized loading factor value), the next step is to look at the internal consistency reliability of the Cronbach alpha value and composite reliability. Composite reliability is better in measuring internal consistency than Cronbach alpha in the Structural Equation Modeling model because composite reliability does not assume the boot similarity of each indicator. Cronbach alpha tends to underestimate construct reliability compared to composite reliability (Yamin \& Kurniawan, 2011).

The interpretation of composite reliability is the same as Cronbach's alpha. A limit value of 0.7 or above means acceptable and above 0.8 , and 0.9 means very satisfying. Another measure of convergent validity is the average variance extracted (AVE) value. This value illustrates the magnitude of variance or diversity of manifest variables that can be contained by latent constructs. The use of AVE for a criterion in assessing the convergent validity of at least 0.5 indicates a good measure of convergent validity. That is, latent variables can explain the average of half the variance of the indicators (Yamin \& Kurniawan, 2011).

\section{Discriminant Validity}



Decisions in Fintech Syariah

Discriminant validity is done in two stages, namely through the crossloading value and comparing the AVE value with the quadratic correlation value between constructs (or comparing the AVE root with the correlation between constructs). Cross loading is measured by comparing the correlation of indicators with their constructs, and the constructs of other blocks with the size of the correlation between indicators with their constructs must be higher than correlations with the constructs of other blocks. After that, comparing the correlation with AVE root extract, the value of AVE root must be higher than the correlation between construct and other constructs, or the AVE value is higher than the correlation of correlation between constructs (Yamin \& Kurniawan, 2011).

\section{Evaluation of Structural Model (Inner Model)}

The structural model is also called the inner model. Structural models describe the relationship between independent (exogenous) latent variables and dependent (endogenous) latent variables. There are several stages in evaluating structural models. The first is looking at the significance of the relationship between constructs seen from the path coefficient with the T-Statistic test parameters through bootstrapping, looking at the percentage of variance explained by the R-Square value (Abdillah \& Jogiyanto, 2015).

1. Path coefficient with parameter T-statistic test

The path coefficient or Inner model score indicated by the tstatistic value must be above 1.96 for the two-tailed hypothesis and 1.64 for the one-tailed hypothesis for testing hypotheses at alpha $5 \%$ and power $80 \%$.

a. If the value of $\mathrm{t}$ count $>\mathrm{t}$-table, then $\mathrm{HO}$ is rejected, and $\mathrm{H} 1$ is accepted

b. If the value of t count $<\mathrm{t}$-table, then $\mathrm{H} 0$ is accepted, and $\mathrm{H} 1$ is rejected.

2. Coefficient of Determination (R Square)

$\mathrm{R}$ square value is used to measure the level of variation in changes in the independent variable on the dependent variable. The higher the value of $\mathrm{R}$ square means, the better the prediction model of the proposed research model. For example, if the $\mathrm{R}$ square value of 0.7 means that the variation of the dependent variable changes that can be explained by the independent variable is $70 \%$, while other variables outside the proposed model explain the rest. However, R square is not an absolute parameter in measuring the accuracy of the prediction model because the basis of the theoretical relationship is the most critical parameter to explain the causality relationship (Abdillah \& Jogiyanto, 2015).

\section{DISCUSSION}

From the results of statistical tests using PLS data analysis tools, it shows that the Attention variable significantly influences the Interest variable. The Interest variable significantly influences the Search variable. The Search variable significantly influences the Action variable. However, the results of the data analysis indicate that the Action variable does not significantly influence 
Jurnal Ekonomi dan Perbankan Syariah

Vol. 7. No.2, 0ktober 2019: 47-57, ISSN (cet): 2355-1755 | ISSN (online): 2579-6437

$\mathbf{5 5}$

the Share variable, and the Share variable does not significantly influence the Investment Decision variable. More can be seen in the following explanation points:

\section{Effect of Attention on Interest}

In this study, the Attention variable is proxy by two indicators, including messages seen by investors (X1.1); investors pay attention to products (X1.2). In this study, all indicators passed the evaluation stage of the measurement model (outer model). The t-statistic value obtained in the Attention to Interest variable is 4.808 , where the value is higher than the t-table of 1.96. Thus, it can be concluded that $\mathrm{H} 0$ is rejected, and $\mathrm{H} 1$ is accepted. These results indicate that the Attention variable has a significant effect on interest.

\section{Effect of Interest on Search}

In this study, the Interest variable is proxy by two indicators, including interest in the product (X2.1), investors like the message delivered (X2.2). In this study, all indicators passed the evaluation stage of the measurement model (outer model). The t-statistic value obtained in the Interest variable for Search is 3,336, where the value is higher than the t-table of 1.96. Thus, it can be concluded that $\mathrm{H} 0$ is rejected, and $\mathrm{H} 1$ is accepted. These results indicate that the Interest variable has a significant effect on Search.

\section{Effect of Search on Action}

In this study, the Search variable is proxied by three indicators, including further search (X3.1), confidence in the results of information (X3.2), and visiting the website (X3.3). In this study, all indicators passed the evaluation stage of the measurement model (outer model). The value of t-statistics obtained in the variable Search for Action of 2.333, where the value is higher than t-table of 1.96. Thus, it can be concluded that $\mathrm{H} 0$ is rejected, and $\mathrm{H} 1$ is accepted. These results indicate that the Interest variable significantly influences the Action.

\section{Effect of Action on Share}

In this study, the Action variable is proxied by three indicators, including the desire of investors to invest (X4.1), investors consider investing (X4.2), and investors to invest (X4.3). In this study, all indicators passed the evaluation stage of the measurement model (outer model). The t-statistic value obtained in the Action against Share variable is 0.130 , where the value is smaller than the t-table of 1.96. Thus, it can be concluded that H0 is accepted, and H1 is rejected. These results indicate that the Action variable has no significant effect on Share.

The cause of the insignificant influence of the Action variable on Share is possible due to the influence of external factors studied, such as investor satisfaction regarding the products provided by fintech sharia so that investors feel reluctant to provide a review of the product. According to (Lubis \& Andayani, 2017) companies are required to be able to satisfy their customers by creating quality products or services following consumer desires. Service 
quality is the expected level of excellence, and control over the level of excellence is intended to meet customer desires to feel satisfied.

Also, the cause of the insignificant influence of the Action variable on Share can be made possible due to emotional differences related to personal desires to provide comments or not about the experience of investing in Islamic fintech.

\section{Effect of Share on Investment Decisions}

In this study, the Share variable is proxied by two indicators, including the provision of reviews on social media (X5.1) and dissemination of information to family or community (X5.2). In this study, all indicators passed the evaluation stage of the measurement model (outer model). The t-statistic value obtained in the Share variable on investment decisions is 1.547, where the value is smaller than the t-table of 1.96. Thus, it can be concluded that H0 is accepted, and $\mathrm{H} 1$ is rejected. These results indicate that the Share variable has no significant effect on investment decisions.

The cause of the insignificant influence of the Share variable on investment decisions is possible because there are several other considerations related to investment decisions, such as risk considerations made to influence one's investment decisions.

\section{CONCLUSION}

This study aims to analyze the effect of e-marketing using the AISAS model on investment decisions on Islamic fintech. Based on testing, analysis, and discussion, it can be concluded that the Attention variable significantly influences the Interest variable. The Interest variable significantly influences the Search variable. The Search variable significantly influences the Action variable. However, the results of the data analysis show that the Action variable has no effect significant on the Share variable. Also, the Share variable does not significantly influence the Investment Decision variable. This result can be made possible due to other factors that influence, such as the Action variable, there are differences in the level of investor satisfaction with sharia fintech products so that investors do not provide a review of sharia fintech. Furthermore, on the Share variable, other factors influence investors' decisions to invest, such as consideration of existing risks or regarding the company's reputation, thus making investors make investments not only based on information obtained from the internet or friends/colleagues. 
Jurnal Ekonomi dan Perbankan Syariah

Vol. 7. No.2, 0ktober 2019: 47-57, ISSN (cet): 2355-1755 | ISSN (online): 2579-6437

| 57

\section{REFERENCES}

Abdillah, W., \& Jogiyanto. (2015). Partial Least Square (PLS); Struktural Equation Modeling (SEM) dalam Penelitian Bisnis (1st ed.). Yogyakarta: C.V Andi.

Lubis, A. S., \& Andayani, N. R. (2017). Pengaruh Kualitas Pelayanan (Service Quality) Terhadap Kepuasan Pelanggan PT. Sucofindo Batam. Journal of Business 'Administration, 1(2).

Ngafifi, M. (2014). Kemajuan Teknologi Dan Pola Hidup Manusia Dalam Perspektif Sosial Budaya. Jurnal Pembangunan Pendidikan: Fondasi Dan Aplikasi, 2(2), 2.

OJK, O. J. K. (2017). Kajian Perlindungan Konsumen Sektor Jasa Keuangan : Perlindungan Konsumen Pada Fintech (Cetakan Ke). Jakarta: Departemen Perlindungan Konsumen OJK.

OJK, O. J. K. (2019). Perkembangan Fintech Lending ( Pendanaan Gotong Royong on-Line ). Jakarta.

Priansa, D. J. (2017). Komunikasi Pemasaran Terpadu Pada Era Media Sosial. Bandung: CV Pustaka Setia.

Republika. (2018, November). Fintech Syariah Terhambat Syarat Modal Minimum. REPUBLIKA.CO.ID. Retrieved from https://www.republika.co.id/berita/ekonomi/syariahekonomi/18/11/15/pi6cqe383-fintech-syariah-terhambat-syarat-modalminimum

Rofiq, A., Arifin, Z., \& Wilopo. (2012). Pengaruh Penerapan AIDA (Attention, Interest, Desire, Action) Terhadap Keputusan Pembelian.

Sanusi, A. (2011). Metodologi Penelitian Bisnis (Cetakan Ke). Jakarta Selatan: Salemba Empat.

Sugiyama, K., \& Andree, T. (2011). The Dentsu Way. New York: Mc Graw Hill. Sugiyono. (2017). Metode Penelitian Bisnis Pendekatan Kuantitatif, Kualitatif, Kombinasi, dan $R \& D$ (3rd ed.). Bandung: ALVABETA, CV

Tandelilin, E. (2010). Portofolio dan Investasi : Teori dan Aplikasi. Yogyakarta: Kanisius.

Wirawan, W. F., \& Hapsari, P. D. (2016). Analisis AISAS Model Terhadap Product Placement Dalam Film Indonesia. Studi Kasus : Brand Kuliner di Film Ada Apa Dengan Cinta 2. Rekam, 12(2).

Yamin, S., \& Kurniawan, H. (2009). Structural Equation Modeling; Belajar Lebih Mudah Teknik Analisis Data Kuisioner dengan Lisrel-PLS. Jakarta: Salemba Infotek.

Yamin, S., \& Kurniawan, H. (2011). Generasi Baru Mengolah Data Penelitian dengan Partial Least Square Path Modeling; Aplikasi dengan Software XLSTAT, SmartPLS, dan Visual PLS. Jakarta: Salemba Infotek 